MOMČILO DOBRODOLAC, Ph.D. ${ }^{1}$

(Corresponding author)

E-mail: m.dobrodolac@sf.bg.ac.rs

PREDRAG RALEVIĆ, Ph.D. ${ }^{2}$

E-mail: ralevicpredrag@gmail.com

LIBOR ŠVADLENKA, Ph.D. ${ }^{3}$

E-mail: Libor.Svadlenka@upce.cz

VALENTINA RADOJIČIĆ, Ph.D. ${ }^{1}$

E-mail: valentin@sf.bg.ac.rs

${ }^{1}$ University of Belgrade, Faculty of Transport and Traffic

Engineering

Vojvode Stepe 305, 11000 Belgrade, Serbia

2 Technical College of Applied Sciences Uroševac

24. Novembar 1, Leposavić 38218, Serbia

${ }^{3}$ University of Pardubice, Jan Perner Transport Faculty

Studentská 95, 53210 Pardubice, Czech Republic
Transportation Economy

Preliminary Communication

Submitted: May 14, 2015

Accepted: Apr. 12, 2016

\title{
IMPACT OF A NEW CONCEPT OF UNIVERSAL SERVICE OBLIGATIONS ON REVENUE INCREASE IN THE POST OF SERBIA
}

\begin{abstract}
The European postal directives and Serbian legislation as well define the quality standards for universal service obligations at the aggregate level, i.e. for all postal items transferred by the postal operator. This paper proposes a new concept where the transit time is defined by the customer and specified for each shipment. The paper considers three different models of this new concept. However, the one where a customer could choose between two alternatives: $D+1$ and $D+3$ transfer, is analysed in details. By using the attitudes of examined customers, forecasting methods and analysis of revenues from the past, it is assessed at what price the new postal service should be offered to achieve the highest revenue. The proposed methodology was tested and verified in the case of the Post of Serbia. The results indicate that the best would be to offer the service D+1 at the 40\% increased price compared to the existing prices.
\end{abstract}

\section{KEY WORDS}

universal service obligations; new concept; transit time; forecasting; customer attitudes; revenue analysis;

\section{INTRODUCTION}

A modern society cannot be imagined without an efficient postal system. The postal services support the economy, normal life of citizens as well as the functioning of the state institutions. This is the reason why there are regulations which imply that some scope of postal services must be provided at the whole state territory, at an affordable price to everybody. These services are referred to as universal postal services or universal service obligations (USO).

The state designates at least one postal operator to serve as a universal service provider (USP). These obligations create some new business possibilities for the postal company, but on the other hand they make the additional costs of functioning which could be avoided if the business were run on the commercial basis. It is a global question in the postal sector how to assess and reimburse these costs. Frontier Economics [1] conducted a study for the European Commission on the principles used by the national regulatory authorities (NRAs) and the USPs to calculate the net cost of the USO. Possible approaches for these types of calculations are also described by the CERP - European Committee for Postal Regulation [2]. On the other hand the financial mechanisms for the costs reimbursement as discussed in the literature $[3,4]$ include the following: reserved area, compensation funds of various forms, state funding, pay-or-play (a tax where the entrant pays a fixed amount per each address it does not cover) and competitive tendering.

Regardless of the methodology used to assess the net cost of USO or implemented financial mechanism for the cost reimbursement, the USO affects all stakeholders in the postal sector: the USPS, other companies in the field, consumers and government. This is the reason why the minimization of these costs is of particular interest to all of them. The goal of this paper is to propose a possible solution for this phenomenon. The starting point is that resource optimization of USP greatly depends on the technology of transferring the shipment. A general rule says that there are four phases in this process: collection, sorting, transportation and delivery. Having in mind that the highest costs are related to the delivery phase [5], the essence of the new concept of USO lies in the improvement of the final transfer phase. 
Therefore, the purpose of the new concept of USO is to reduce the costs and to increase the revenue of the postal operator. The main goal of this paper is to explain how the costs could be reduced by introducing this new concept and to propose a methodology for the new service price determination in function of revenue maximization.

The following hypotheses have been set:

$1^{\text {st }}$ Hypothesis: The new concept of USO reduces the operating costs of USP due to technological change in the production process, first of all in the final phase - delivery.

$2^{\text {nd }}$ Hypothesis: By introducing the new concept of USO, a higher revenue could be achieved compared to the actual one.

$3^{\text {rd }}$ Hypothesis: By implementing the methodology proposed in this study it is possible to determine the price of new postal service which should bring the highest revenue achievements.

In this study the second and third hypotheses are mathematically grounded and proved, while the first is just conceptually set since its proving would request the analysis of the whole delivery network, all units and mailmen routes in the country which would exceed the expected volume of the current paper. However, the first hypothesis is set in order to indicate the benefits of the proposed model. It is intuitively clear that it leads to the reduction in costs due to engagement of part-time workers instead of the full-time employees.

The paper proceeds as follows. In Section 2, the traditional USO is described. In Section 3, a new concept of USO is presented. Further, in Section 4, the demand for new postal service is forecast by using the Bass diffusion model. The input parameters for the model are obtained by using the analogy with the traffic volumes of express mail service from its beginning, analysis of mail and parcel volumes from the past and by considering the attitudes of examined customers. At the end, a revenue analysis is performed to gain the information about the price of new postal service which should bring the highest revenue to the USP. The conclusions are given in Section 6.

\section{TRADITIONAL CONCEPT OF UNIVERSAL SERVICE OBLIGATIONS}

Universal postal service or universal service obligations (USO) represent a set of measures aiming to grant permanently all users at all points of a territory a sufficient level of service at affordable price. This universal service involves quality in the broad sense, and price controls. The existence of USO means that, in its absence, the market may not provide a sufficient level of service, or the whole scope of products, or at least not at an affordable price level for all users [6].

Considering the quality standards related to the transit times on the territory of the European Union they are defined by the Postal Directives [7, 8, 9]. The quality standards for intra-Community cross-border mail in each country are to be established in relation to the time limit for routing measured from end to end for postal items of the fastest standard category according to formula $\mathrm{D}+n$, where $\mathrm{D}$ represents the date of deposit and $n$ the number of working days which elapse between that date and the date when an item is delivered to the addressee. The date of deposit to be taken into account shall be the same day as that on which the item is deposited, provided that deposit occurs before the last collection time notified from the access point. When the deposit takes place after this time limit, the date of deposit to be taken into consideration will be that of the following day of collection. The exact values of standards are shown in Table 1. The standards must be achieved not only for the entirety of intra-Community traffic but also for each of the bilateral flows between two Member States. Independent performance monitoring shall be carried out at least once a year by external bodies having no links with the universal service providers. The technology used for this purpose is mainly based on AMQM systems [10].

Table 1 - Quality standards for intra-Community crossborder mail in European Union [7]

\begin{tabular}{|c|c|}
\hline \hline Time limit & Objective \\
\hline$D+3$ & $85 \%$ of items \\
\hline$D+5$ & $97 \%$ of items \\
\hline
\end{tabular}

Since the Serbian legislation follows the regulations of the EU, the criteria of the same type are valid for the Serbian USP. The regulatory agency for electronic communications and postal services - RATEL, established the specific quality standards as shown in Table $2[11,12]$.

Table 2 - Quality standards for domestic items in the Republic of Serbia [11, 12]

\begin{tabular}{||c|c|c|}
\hline \multirow{2}{*}{ Time limit } & \multicolumn{2}{|c|}{ Objective } \\
\cline { 2 - 3 } & Letters & Parcels \\
\hline \hline$D+2$ & $90 \%$ & $85 \%$ \\
\hline$D+3$ & $98.5 \%$ & $95 \%$ \\
\hline$D+5$ & $99.5 \%$ & $99 \%$ \\
\hline
\end{tabular}

Both the standards in the European Union and Serbia refer to the average number of all transferred items by the postal company; accordingly, a customer using this type of postal service cannot get a guarantee that their specific postal item would be delivered in the specified period of time. The new concept of postal service that is proposed in this paper offers precisely this possibility to the customer. 


\section{A NEW CONCEPT OF UNIVERSAL SERVICE OBLIGATIONS}

The proposed new concept of USO has two main aims: to improve the quality of the postal service and to increase the profit of the postal company. Higher quality should be achieved by giving the customer a possibility to choose the exact transit time for their shipment. Accordingly, if the chosen transit time is shorter the postage would be higher and in the opposite case the customer should pay less. When it comes to profit, a new concept should reduce the operating costs and bring additional revenue.

The new concept would imply the possibility for the customer to choose the transit time $\mathrm{D}+1$ which means the next day delivery or some other longer period. The importance of this new concept is not just in a new service portfolio or new marketing approach; the emphasis is on the fact that this type of postal service changes the requirements in terms of the technological process of mail transferring. What is particularly important is a significant change related to the last stage in the technological process - delivery. Bearing in mind that this is a phase that involves the highest costs for a postal operator in relation to all the other stages, it is clear that the optimization of this stage is of great importance.

The delivery would be organized every day just for those items that are received as $D+1$ shipment. For all other mail the delivery would be done three times a week or twice a week. This concept would result in the fact that the delivery volumes are significantly higher on two or three specific days of the week.

This type of delivery allows human resource optimization. For the delivery of $D+1$ items, permanently employed workers could be engaged who work every working day and their number could be defined in such a way as to be able to deliver all the $D+1$ shipment items. On two or three specific days of the week which are subject to higher delivery volumes, part-time workers could be engaged who imply lower costs for the postal operators. It should be noted that in such a concept the tasks of full-time employees and parttime workers would not be split in terms of deliveries of priority or non-priority shipments. To achieve a rationalization of costs, each postman, both the full-time and the part-time one engaged should deliver any type of shipment. The distribution of postal items among all of them should be done based on the appropriate software solutions which use the distance and delivery deadlines as the basic input parameters.

The proposed new concept has certain similarities with a widely accepted concept in many countries of priority and non-priority items. There are two general differences. The first difference refers to the new concept of delivery. Accordingly, human resource optimization is achieved. The second difference lies in the fact that the new concept should offer postal service of a higher quality. It means that a customer could demand postal service with the exactly defined transit time. This time could be $D+1$ or longer. Depending on the alternative to the $D+1$ transfer, the new concept of USO can be designed in three ways. Table 3 shows three possible alternatives. The first case means that the alternative to $D+1$ shipment is a time limit $D+2$ for which a postal item should be delivered. The second case includes $D+3$ transfer as an alternative to $D+1$. The third method is characterized by two possible alternatives to $D+1$; a customer can further choose $D+2$ or $\mathrm{D}+3$ transfer.

Table 3 - The possible alternatives of a new concept of USO

\begin{tabular}{||c|c||}
\hline Alternative & Time limits to be chosen \\
\hline \hline Alternative I & $D+1$ or $D+2$ \\
\hline Alternative II & $D+1$ or $D+3$ \\
\hline Alternative III & $D+1, D+2$ or $D+3$ \\
\hline
\end{tabular}

\subsection{Alternative I}

Alternative I represents the case where a customer can choose between $D+1$ and $D+2$ transfer. This concept implies that delivery should be organized in the way as illustrated in Figure 1.

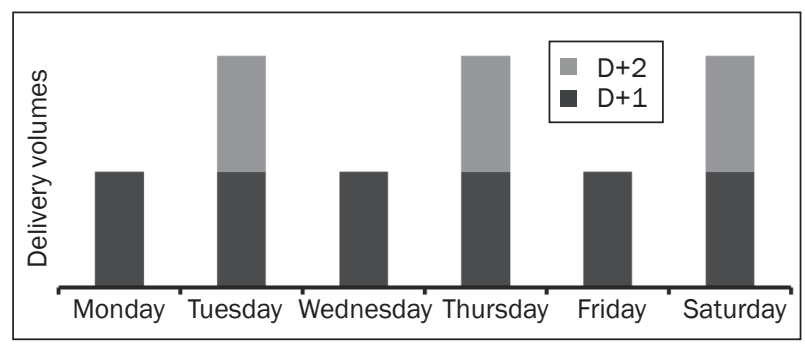

Figure 1 - The concept of delivery in Alternative I

There are three very busy days during the week (Tuesday, Thursday and Saturday). On Monday just D+1 items should be delivered, that have been sent on Saturday the previous week. Tuesday is one of the very busy days when delivery should be organized for the following items: $D+1$ items collected the day before and D+2 items collected on the previous week Saturday and this week Monday. On Wednesdays just $\mathrm{D}+1$ items from the previous day will be delivered. Thursday is also a very busy day when delivery should include the following: $D+1$ items sent on Wednesday and $D+2$ sent on Tuesday and Wednesday. On Fridays the postal operator should deliver just $D+1$ items from the previous day. Finally, Saturday is introduced as a working day when $D+1$ items sent on Friday and $D+2$ items sent on Thursday and Friday should be delivered. Bearing in mind that this day is for most of the 
people a non-working one, it can be assumed that this is a particularly convenient day for engaging part-time workers.

\subsection{Alternative II}

It has been noted that Alternative II is a case where a customer can choose between $\mathrm{D}+1$ and $\mathrm{D}+3$ transfer. This kind of postal service portfolio gives the possibility to form the delivery system as shown in Figure 2 .

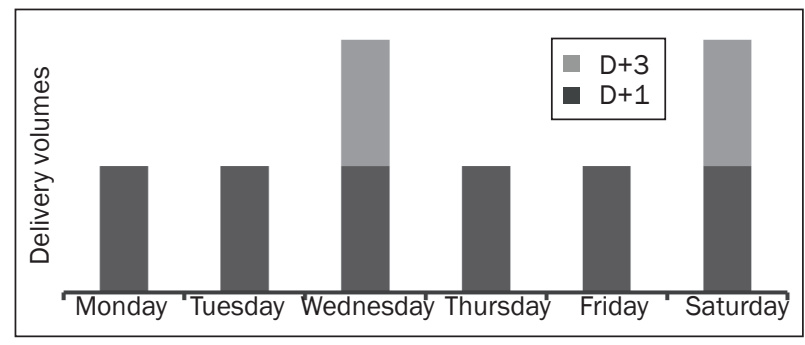

Figure 2 - The concept of delivery in Alternative II

As it can be noticed there are two very busy days (Wednesday and Saturday). On Wednesdays the following postal items should be delivered: $D+1$ collected on Tuesday, D+3 sent on previous week Saturday, as well as D+3 sent on Monday and Tuesday. It means on Wednesday an addressee will receive mail which was sent on Saturday the previous week where a sender requested $D+3$ service; or a mail sent on Monday where a sender also requested $D+3$ service; or a mail sent on Tuesday whatever service the sender requested. This kind of delivery has as a result the fact that certain D+3 mail would be delivered a day or two before the requested deadline. However, from the user's standpoint this is just an unexpected benefit. On the other hand, this benefit may be avoided where this is economically justified which should be decided on a lower organizational level - in the delivery branch.

On Saturdays there are similar delivery requirements as in the case of Wednesday: D+1 items from the previous day and D+3 items from Wednesday, Thursday and Friday should be delivered. On the remaining four working days which are not very busy days, the delivery should be organized just for $D+1$ items deposited one day before. Saturday is a particularly convenient day to be a very busy one because it is expected that most of the working people are free during the weekend and accordingly it would be easier for the postal company to find the part time workers to be engaged on Saturday.

\subsection{Alternative III}

Alternative III considers that a customer has three possible choices: $D+1, D+2$ or $D+3$ transfer. The delivery organization during the working week is shown in Figure 3. As in the case of previous two alternatives, on Mondays the postal company should organize the delivery just for $\mathrm{D}+1$ items deposited two days before - on Saturday. On Tuesdays, D+1 items from the previous day and $D+2$ items from Saturday should be delivered. Finally, there are four very busy days when delivery is organized for all types of items: $D+1, D+2$ and $\mathrm{D}+3$. These days are Wednesday, Thursday, Friday and Saturday.

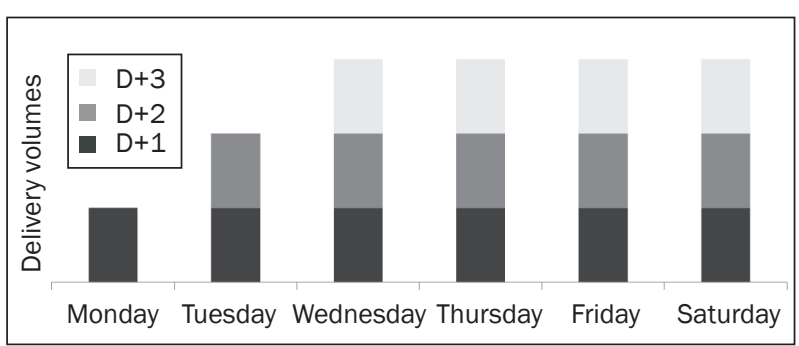

Figure 3 - Concept of delivery in Alternative III

The purpose of introducing the new concept of USO is the ability to rationalize the delivery on the ground that certain working days of the week have significantly increased delivery volumes. Based on a comparison of the previous three alternatives, it could be intuitively concluded that Alternative II has the greatest potential for rationalization of delivery because it has the least number of days with peak volumes. To confirm this conclusion, further calculations should be necessary which involve analysis of the total delivery network in terms of costs in the case of all three alternatives and in the case of traditional USO. This could be a potential further research direction. In the next section we will examine the revenue effects of Alternative II implementation in the case of USP from Serbia.

\section{FORECASTING A NEW POSTAL SERVICE DEMAND}

Alternative II was tested in the case of the Post of Serbia. As previously explained, a customer can choose between $D+1$ and $D+3$ transfer. $D+1$ transit time as an offer is a novelty in the field of traditional postal services. In the further text this service is called "a new postal service". It is assumed that the new concept was introduced in the year 2014. Therefore, forecasting demand for the new postal service is assessed for the period from 2015 to 2025 . The method used for this purpose is the one proposed by Bass [13]. This model has found an important application primarily in predicting acceptance of new services and technologies. The Bass diffusion model describes the process of acceptance of new services through the interaction between the existing and potential users.

According to the Bass model the process of accepting a new service is a result of two independent 
influences. The first influence is related to the mass media which means that through the advertising they affect the innovative users to accept the new service. Another influence on the diffusion is based on the transmission of information about the experience gained by the users who have already accepted the new service by speaking about it. This effect is known in literature as WoM - Word of Mouth effect. By comparing these two influences on the speed of diffusion, it was indicated that WoM effect has greater impact [14]. Both influences are quantified in this model through parameters of innovation and imitation, re spectively. The innovation parameter is the probability of the initial acceptance of new services immediately after a service has been launched on the market. The imitation parameter is the probability of subsequent acceptance of innovation in a society. Generally, according to the model, the innovators and imitators participate in the acceptance of new services, and new users are formed when innovators communicate about their experiences to imitators. The model is mathematically explained by the following formulas [15]:

$$
N(t)=m \frac{1-e^{-(p+q) t}}{1+\frac{q}{p} e^{-(p+q) t}}
$$

where $N(t)$ is the cumulative number of users at some point of time $t ; p$ denotes a parameter of innovation; $q$ is an imitation parameter; while $m$ indicates the market potential, i.e. all potential users of a new service. The final equation in the model describes the number of new users $s(t)$ of the observed service at time $t$ [15]:

$$
\begin{aligned}
s(t)= & p m+(q-p) m \frac{1-e^{-(p+q) t}}{1+\frac{q}{p} e^{-(p+q) t}}- \\
& -q m\left[\frac{1-e^{-(p+q) t}}{1+\frac{q}{p} e^{-(p+q) t}}\right]^{2}
\end{aligned}
$$

\subsection{Calculation of the Bass diffusion parameters}

Estimation of the parameters $p, q$ and $m$ is required to identify the diffusion curve. Bass model could be used to predict the timing and magnitude of the sales peak and shape of the diffusion curve. The applicability of Bass model depends on the accuracy of assessing the model's parameters. It is possible to assess parameters $p$ and $q$ in two ways; before the introduction of a new service or based on the statistical database. The former implies the implementation of some market research technique such as: survey method, Delphi method, brainstorming, comparison method, etc. or using the analogy with another service for which parameters $p$ and $q$ are known. The latter way, after the introduction of a new service, is to assess $p$ and $q$ parameters by using various mathematical techniques from which the most known are [15]: Ordinary least squares, Maximum likelihood estimation, Non-linear least squares.

In the considered case of the new postal services, $p$ and $q$ parameters are determined by using the analogy with the number of express items in the same company - The Post of Serbia. We used this analogy because $D+1$ service has a similar concept as express service. This is particularly evident if we analyze which type of express service is the most used by the customers in Serbia. The Post of Serbia offers three types of express service: "Today for immediately" where the transit time is not more than a few hours, "Today for today" where the mail should be delivered the same day until 8 p.m. and "Today for tomorrow" where the transit time is actually $D+1$. It is interesting that the service "Today for tomorrow" is the most commonly used in around $95 \%$ of cases. This is the reason why the appearance of express service could be used as something similar to the appearance of the proposed new concept. The basic difference between the service "Today for tomorrow" and the new D+1 concept is in three ways. Express service is an elite postal service which means the sender can demand it even from his home or business address and the postal company will collect the shipment exactly according to the customer request. On the other hand, D+1 service should be requested only in the Post Office. The second difference may be in the postal process. For example, express items are always individually tracked while $D+1$ item could be transferred as ordinary mail. The third difference may be in delivery phase where express items have a priority.

Express service was introduced as a new service by the Post of Serbia in 2002. For $p$ and $q$ parameters calculation the considered traffic volumes were in the period from January 2003 to December 2012 (Table 4). The mathematical technique that was chosen for this purpose was the method of least squares. When the method of least squares regression is applied to the analogy of the basic form of the Bass model that was introduced in (2), this yields the objective function as presented in (3).

$$
S(a, b, c)=\sum_{t=1}^{n}\left(s_{t}-a-b N_{t-1}-c N_{t-1}^{2}\right)^{2}
$$

The regression parameters $a, b$ and $c$ are calculated by condition of minimization $\left(\frac{\partial S}{\partial a}=0, \frac{\partial S}{\partial b}=0\right.$ and $\left.\frac{\partial S}{\partial c}=0\right)$ of function $S(a, b, c)$. This implies the system of three linear equations (4) with three unknowns (a, $b$ and $c$ ). The regression parameters are obtained by solving the system of equations (4). Finally, the parameters of the Bass model $p$ and $q$ are calculated as $p=\frac{-b+\sqrt{b^{2}-4 a c}}{2}$ and $q=\frac{b+\sqrt{b^{2}-4 a c}}{2}$. 


$$
\begin{aligned}
& a n+b \sum_{t=1}^{n} N_{t-1}+c \sum_{t=1}^{n} N_{t-1}^{2}=\sum_{t=1}^{n} s_{t} \\
& a \sum_{t=1}^{n} N_{t-1}+b \sum_{t=1}^{n} N_{t-1}^{2}+c \sum_{t=1}^{n} N_{t-1}^{3}=\sum_{t=1}^{n} s_{t-N t-1} \\
& a \sum_{t=1}^{n} N_{t-1}^{2}+b \sum_{t=1}^{n} N_{t-1}^{3}+c \sum_{t=1}^{n} N_{t-1}^{4}=\sum_{t=1}^{n} s_{t-N_{t-1}^{2}}
\end{aligned}
$$

Table 4 - The volume of express items from 2003 to 2012 [16]

\begin{tabular}{||c|c|c|c||}
\hline \hline Year & Express items & Year & Express items \\
\hline \hline 2003 & 205,481 & 2008 & $2,632,730$ \\
\hline 2004 & 516,243 & 2009 & $2,717,231$ \\
\hline 2005 & 783,702 & 2010 & $3,233,102$ \\
\hline 2006 & $1,262,334$ & 2011 & $4,020,254$ \\
\hline 2007 & $1,950,128$ & 2012 & $4,799,189$ \\
\hline
\end{tabular}

Based on (4), there are $a=0.556, b=0.386$ and $c=-0.009$. Accordingly, the parameters of Bass model are $p=0.012$ and $q=0.398$. It means that at the postal market of Serbia there are $1.2 \%$ of innovators and around $40 \%$ of imitators. These values are consistent with the values from the relevant literature. Typical values of $p$ and $q$ when time $t$ is measured in years are $[16,17]$ : the average value of $p$ has been found to be 0.03 , and it is often less than 0.01 ; the average value of $q$ has been found to be 0.38 , with a typical range between 0.3 and 0.5 . Thus, it could be concluded that the chosen analogy with express service was reasonable.

\subsection{Calculation of the market potential in the case of a new postal service}

The size of the market potential is probably the most critical element in forecasting matters. The total market potential consists of all potential users of some new service. It depends on the total population, number of households, economic status of individuals and society as a whole, demographic structure, birth rate, presence of competition on the market, user habits, etc.

For the observed new postal service, it is assumed that the market potential represents the existing volumes of mail and parcel items transferred by the Post of Serbia; where the letter post includes letters, postcards, printed matters and literature for the blind, while the parcels represent the packaged and addressed goods which are transferred as registered or insured shipment. This analysis has not included the packages that are related to the express service because this service implies an additional quality such as the arrival of the courier at the sender's address; therefore, it is not within the concept of the new services proposed in this study.
It was assumed that the market potential, i.e. parameter $m$ of the Bass model is the forecast number of letter and parcel items for the year 2025. In the case of USP from Serbia, the market potential has been determined by using the time series analysis, based on statistical data about the number of letter and parcel items shown in Table 5, for the period of time from the year 2003 to 2012 .

Table 5 - The volume of letter and parcel items from 2003 to 2012 [16]

\begin{tabular}{||c|c|c|c||}
\hline Year & Letter items & Parcel items & Total \\
\hline \hline 2003 & $170,610,410$ & $1,156,033$ & $171,766,443$ \\
\hline 2004 & $216,489,851$ & $1,125,112$ & $217,614,963$ \\
\hline 2005 & $266,096,680$ & $1,099,765$ & $267,196,445$ \\
\hline 2006 & $254,231,396$ & $1,408,282$ & $255,639,678$ \\
\hline 2007 & $264,363,440$ & 881,242 & $265,244,682$ \\
\hline 2008 & $290,091,805$ & 744,108 & $290,835,913$ \\
\hline 2009 & $272,684,936$ & 628,464 & $273,313,400$ \\
\hline 2010 & $284,754,082$ & 518,560 & $285,272,642$ \\
\hline 2011 & $295,316,223$ & 514,868 & $295,831,091$ \\
\hline 2012 & $305,758,709$ & 503,275 & $306,261,984$ \\
\hline
\end{tabular}

Time series analysis is a statistical trend method. These methods analyze the observed statistical data, finding the rule or pattern of their values in time, and accordingly on the basis of established rules project data on the future. There are various types of mathematical curves used in the analysis of time series data. For example, exponential, logarithmic, polynomial curves, straight lines or extrapolation obtained by "free-hand" method can be used.

In the case of the Post of Serbia time series consists of ten observations, i.e. the total number of letter and parcel items per year that are transferred by the operator for the period 2003-2012. This time the series is presented graphically in Figure 4.

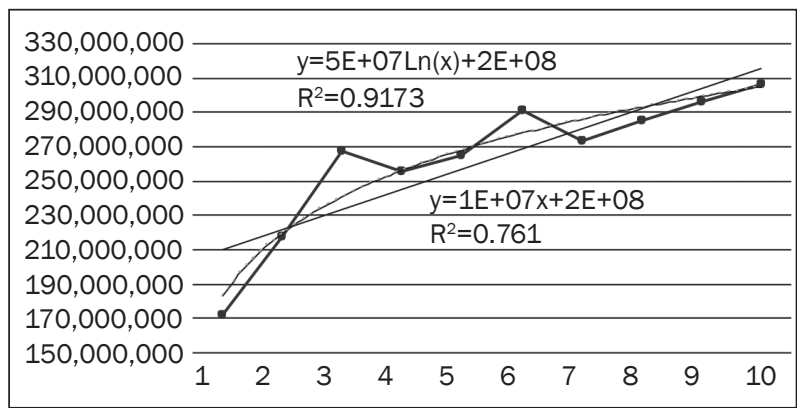

Figure 4 - Total number of letter and parcel items from 2003 to 2012

Furthermore, the trend between the total number of items and time is examined. Based on the 
comparison of Pearson's correlation coefficient between the linear trend (0.8724) and logarithmic trend (0.9578), it has been found that there is a logarithmic trend between the total number of items and time. The results of market potential forecasting are obtained by extrapolating the logarithmic trend, as shown in Table 6.

Table 6 - The forecasted number of letter and parcel items from 2015 to 2025

\begin{tabular}{||c|c|c|c||}
\hline Year & No. of items & Year & No. of items \\
\hline \hline 2015 & $328,247,468$ & 2021 & $347,221,949$ \\
\hline 2016 & $331,952,866$ & 2022 & $349,786,614$ \\
\hline 2017 & $335,402,510$ & 2023 & $352,226,122$ \\
\hline 2018 & $338,629,436$ & 2024 & $354,552,123$ \\
\hline 2019 & $341,660,667$ & 2025 & $356,774,711$ \\
\hline 2020 & $344,518,588$ & & \\
\hline
\end{tabular}

According to the results from Table 6, the forecast market potential for the year 2025 is 356,774,711 letters and parcels which is close to saturation. Since the users in the new concept of USO can choose a new $\mathrm{D}+1$ or traditional postal service $\mathrm{D}+3$, to determine parameter $m$ of the Bass model, it is necessary to perform the distribution between $D+1$ and $D+3$ services depending on the price. For this purpose, we conducted a survey examining 214 users who used domestic postal services and did not use the express service at the moment of examination. The questionnaire contained 11 questions; however, for the topic of this study, the most important is the distribution of answers related to the selection of $D+1$ service depending on the percentage increase of price compared to the one which the user paid at the moment of interviewing. This is shown by Table 7 . The results illustrate the customers' level of willingness to pay a higher price for $D+1$ service in relation to the existing price for $D+3$ service. For example, $16.82 \%$ of the respondents (36 out of 214) who responded that they were not willing to pay a higher price means that they are not interested in using the new postal service. The remaining $83.18 \%$ of respondents (178 of them) were willing to pay a higher price for the new service.

A further analysis of Table 7 gives information about the amount of money the customers are willing to pay for $D+1$ service. For example, around $10 \%$ of the respondents (23 out of 214) said that they were willing to pay $30 \%$ higher price for the new service. If the price was set to be $30 \%$ higher, in the calculation of revenue those should be included who are willing to pay even a higher price. Therefore, besides 23 respondents also 26 and 67 of them should be considered who would use $D+1$ service even if the price would increase by $40 \%$ or $50 \%$, respectively. In total, in the case of $30 \%$ higher price, $54.21 \%$ would use the new service. This means that the market potential for $D+1$ service in 2025 , in the case of $30 \%$ price increase, would be around 194 million items. Analogously, the market potentials in other cases (increase of 10\%, 20\%, 40\% and $50 \%$ ) can be calculated. The results are shown in Table 8.

Table 8 - Market potential for $D+1$ service

\begin{tabular}{|c|c|c|}
\hline \hline$i$ & Price increase (\%) & Market potential, $m_{i}$ \\
\hline \hline 1 & 50 & $111,706,162$ \\
\hline 2 & 40 & $155,054,289$ \\
\hline 3 & 30 & $193,407,571$ \\
\hline 4 & 20 & $243,391,708$ \\
\hline 5 & 10 & $296,765,205$ \\
\hline
\end{tabular}

\subsection{Implementation of the Bass model for $D+1$ service demand forecasting}

Since we obtained all the necessary parameters for the implementation of the Bass model, in this section $D+1$ service demand forecasting is performed for the period from 2015 to 2025 . The calculations are done for five cases depending on the price of D+1 service: increase of $10 \%, 20 \%, 30 \%, 40 \%$ and $50 \%$ compared to the existing prices. Based on the values of $p, q$ and $m_{i}$ parameters, the cumulative number of $D+1$ postal services is calculated according to Formula 5. The results are shown in Figure 5.

Table 7 - Distribution of answers related to choosing $D+1$ service depending on price

\begin{tabular}{|c|c|c|c|c||}
\hline Price increase (\%) & No. of answers & No. of answers (\%) & $\begin{array}{c}\text { Cumulative No. of } \\
\text { answers }\end{array}$ & $\begin{array}{c}\text { Cumulative No. of } \\
\text { answers (\%) }\end{array}$ \\
\hline \hline 0 & 36 & 16.82 & 0 & 0 \\
\hline 50 & 67 & 31.31 & 67 & 31.31 \\
\hline 40 & 26 & 12.15 & 93 & 43.46 \\
\hline 30 & 23 & 10.75 & 116 & 54.21 \\
\hline 20 & 30 & 14.02 & 146 & 68.22 \\
\hline 10 & 32 & 14.95 & 178 & 83.18 \\
\hline$\Sigma$ & 214 & 100 & & \\
\hline
\end{tabular}


$N_{i}(t)=m_{i} \frac{1-e^{-0.41 t}}{1+33.17 e^{-0.41 t}},(i=1,2, \ldots, 5)$

It can be noticed that the cumulative number of $\mathrm{D}+1$ items is heavily influenced by the price variations. For example, the number of D+1 items in Serbia is expected to be higher for $134,000,000$ in case of $10 \%$ price increase compared to the $50 \%$ increase observing the year 2025.

\section{REVENUE ANALYSIS IN THE FUNCTION OF DIFFERENT PRICES}

The revenue analysis of the new concept of USO is performed in the case of USP from Serbia for the period from 2015 to 2025 . This implies the calculation of the total revenue achieved in this period in six cases: five of them which have been previously considered related to the increase of price $(50 \%, 40 \%, 30 \%, 20 \%$ and $10 \%)$ and the sixth case is the situation without any changes, i.e. if the new concept were not introduced.

The Post of Serbia achieved operational revenue in the amount of SDR 164,458,881 [18] for the year 2012. If the total number of transferred postal items is considered $(306,261,984)$, the average revenue per postal item is SDR 0.5370. If the price is increased by $50 \%$, then the average revenue per item would be SDR 0.8055 . According to this, and having in mind the forecast demand, analytical results are shown in Table 9.

Analogously, the revenue analysis can be performed in the cases of other considered price increasing: for $40 \%$ (the average price is SDR 0.7518 ), 30\% (SDR 0.6981), 20\% (SDR 0.6444), 10\% (SDR 0.5907)

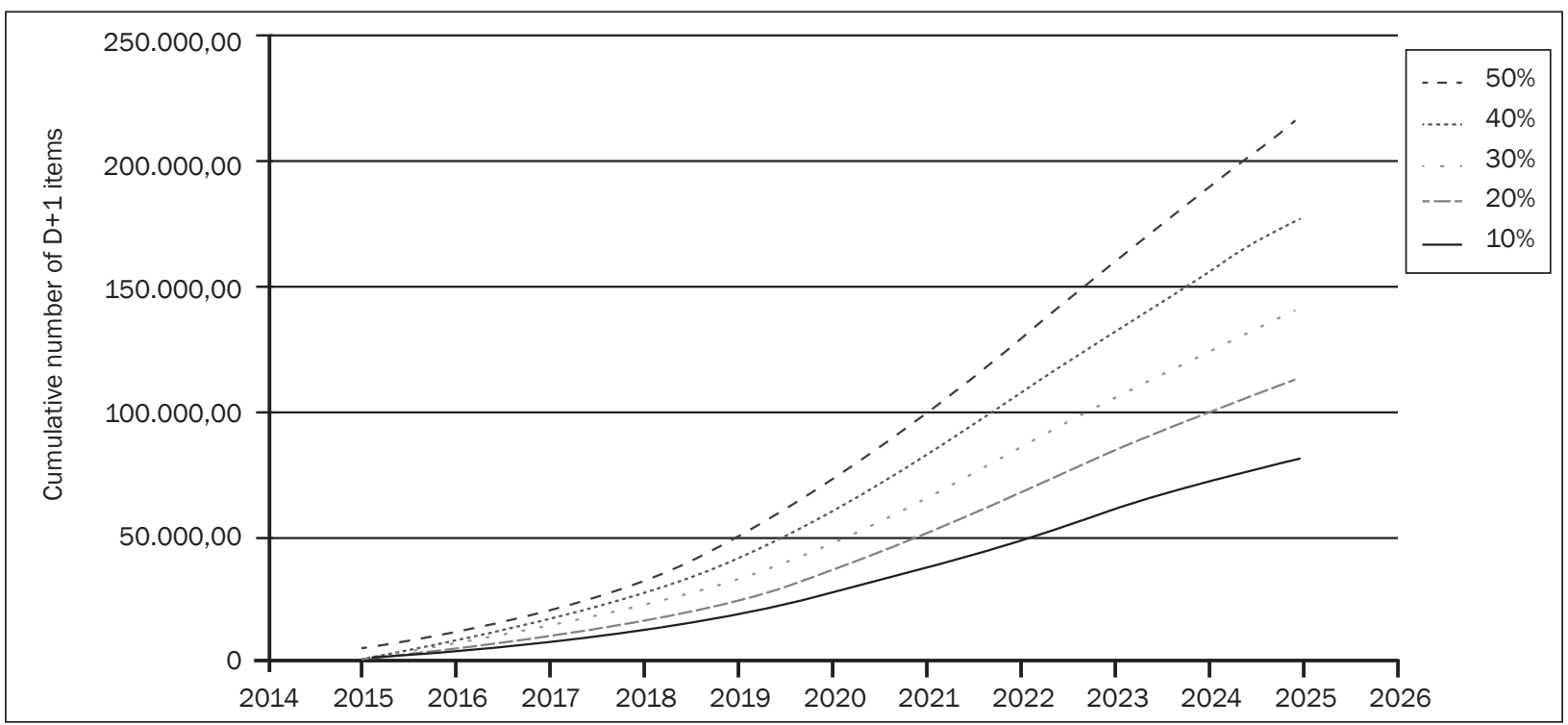

Figure 5 - Cumulative number of D+1 items from 2015 to 2025

Table 9 - Revenue analyzis in the case of $50 \%$ increse in price of $D+1$ service

\begin{tabular}{||c|c|c|c|c|c||}
\hline Year & D+1 items & $\begin{array}{c}\text { Revenue from } \\
\text { D+1 items (SDR) }\end{array}$ & D+3 items & $\begin{array}{c}\text { Revenue from } \\
\text { D+3 items (SDR) }\end{array}$ & Total revenue (SDR) \\
\hline \hline 2015 & $1,654,307$ & $1,332,544$ & $326,593,161$ & $175,380,527$ & $176,713,072$ \\
\hline 2016 & $4,056,642$ & $3,267,625$ & $327,896,224$ & $176,080,273$ & $179,347,898$ \\
\hline 2017 & $7,484,910$ & $6,029,095$ & $327,917,600$ & $176,091,751$ & $182,120,846$ \\
\hline 2018 & $12,257,394$ & $9,873,331$ & $326,372,042$ & $175,261,787$ & $185,135,117$ \\
\hline 2019 & $18,676,742$ & $15,044,116$ & $322,983,925$ & $173,442,368$ & $188,486,484$ \\
\hline 2020 & $26,923,459$ & $21,686,846$ & $317,595,129$ & $170,548,584$ & $192,235,430$ \\
\hline 2021 & $36,914,208$ & $29,734,395$ & $310,307,741$ & $166,635,257$ & $196,369,651$ \\
\hline 2022 & $48,192,433$ & $38,819,005$ & $301,594,181$ & $161,956,075$ & $200,775,080$ \\
\hline 2023 & $59,952,489$ & $48,291,730$ & $292,273,633$ & $156,950,941$ & $205,242,671$ \\
\hline 2024 & $71,242,398$ & $57,385,752$ & $283,309,725$ & $152,137,322$ & $209,523,074$ \\
\hline 2025 & $81,253,067$ & $65,449,345$ & $275,521,644$ & $147,955,123$ & $213,404,468$ \\
\hline Total & $368,608,049$ & $296,913,783$ & $3,412,365,005$ & $1,832,440,007$ & $2,129,353,791$ \\
\hline
\end{tabular}


compared to the price of $\mathrm{D}+3$ service (the average price is SDR 0.5370). The final relationship between the considered cases is shown in Figure 6.

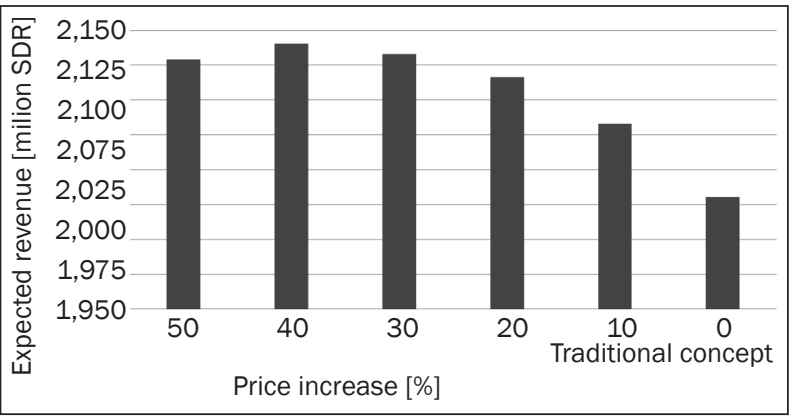

Figure 6 - The forecast revenue of the Post of Serbia from 2015 to 2025

If the price increase was $40 \%$ for $D+1$ service, the income from the new postal service would be SDR $384,657,133$, while the revenue from the traditional postal service would be SDR $1,755,627,435$, for the considered period from 2015 to 2025 . In total, the generated revenue would be around SDR 2.14 billion, which is the highest value compared to other four cases of price increase. The interesting fact to notice here is that the introduction of the new concept of USO regardless of the amount of price increase would bring higher revenue compared to the traditional concept. At the same time, according to the conceptual explanation of Hypothesis 1 , the costs are expected to be lower.

\section{CONCLUSION}

The aim of this paper was to explain the new concept of USO and to propose a methodology for its revenue analysis. A basic assumption related to the costs is that by adjusting a postal process to the new concept of USO, particularly in the final phase - delivery, the saving could be achieved. This assumption is conceptually explained; however, further research is necessary to scientifically prove it. Furthermore, based on the proposed methodology it is possible to assess the future revenue of the postal company. By taking the Post of Serbia as a case study, it is demonstrated that the new concept of postal service should bring higher revenue compared to the traditional one. Moreover, the methodology could be used to determine the price of the new postal service which should bring the highest revenue. In this case study, the results show that the increase of $40 \%$ in the price for $D+1$ service would be optimal.

In this study we analyzed the modality of a new concept which is defined as Alternative II. As a direction for further research, it could be possible to analyze the other two modalities: Alternative I and Alternative III.
Besides, it would be useful to perform the sensitivity analysis of costs related to all three alternatives which would involve the consideration of total delivery network of the postal company.

\section{ACKNOWLEDGEMENT}

This research was supported by the Czech Project CZ.1.07/2.3.00/30.0058 and the Ministry of Education, Science and Technological Development of the Republic of Serbia by the Project TR 36022.

\section{Dr MOMČILO DOBRODOLAC ${ }^{1}$}

E-mail: m.dobrodolac@sf.bg.ac.rs Dr PREDRAG RALEVIĆ

E-mail: ralevicpredrag@gmail.com Dr LIBOR ŠVADLENKA ${ }^{3}$

E-mail: Libor.Svadlenka@upce.cz

Dr VALENTINA RADOJIČIĆ ${ }^{1}$

E-mail: valentin@sf.bg.ac.rs

${ }^{1}$ Univerzitet u Beogradu, Saobraćajni fakultet

Vojvode Stepe 305, 11000 Beograd, Srbija

2 Visoka tehnička škola strukovnih studija Uroševac 24. Novembar 1, 38218 Leposavić, Srbija

3 Univerzita Pardubice, Dopravní fakulta Jana Pernera

Studentská 95, 53210 Pardubice, Česká republika

\section{UTICAJ NOVOG KONCEPTA UNIVERZALNE POŠTANSKE USLUGE NA POVEĆANJE PRIHODA POŠTE SRBIJE}

\section{SAŽETAK}

Evropske poštanske direktive, a takođe i regulativa Srbije, definišu standarde kvaliteta univerzalne poštanske usluge na zbirnom nivou, tj. za sve poštanske pošiljke koje prenese poštanski operator. $U$ ovom radu predlaže se novi koncept gde je tranzitno vreme definisano od strane korisnika i određeno za svaku pošiljku. Razmatraju se tri različita modela ovog novog koncepta. Međutim, onaj gde korisnik može birati između alternativa: $D+1$ i $D+3$ prenosa je analiziran detaljnije. Koristeći stavove ispitanih korisnika, metode prognoziranja i analize prihoda iz prošlosti, procenjuje se po kojoj ceni nova poštanska usluga treba da se ponudi da bi se postigao najveći prihod. Predložena metodologija je testirana i potvrđena u slučaju Pošte Srbije. Rezultati pokazuju da bi bilo najbolje ponuditi uslugu $D+1$ po ceni koja je za $40 \%$ veća u odnosu na postojeće cene.

\section{KLUČNE REČI}

univerzalna poštanska usluga; novi koncept; tranzitno vreme; prognoziranje; stavovi korisnika;

\section{REFERENCES}

[1] Frontier Economics. Study on the principles used to calculate the net costs of the postal USO - a report prepared for the European Commission. London: Frontier Economics; 2013 [cited 2014 May 29]. Available from: http://ec.europa.eu/internal_market/post/doc/ studies/2012-net-costs-uso-postal_en.pdf 
[2] CERP - European Committee for Postal Regulation. Guidelines for calculating the net cost of the universal service obligations. Copenhagen: CERP - European Committee for Postal Regulation; 2008 [cited 2014 Sep 12]. Available from: http://www.cept.org/files/1049/ documents/List\%20of\%20documents\%20(history)/ Guidelines\%20Calculation\%20net\%20costs\%20USO. pdf

[3] Gautier A, Paolini D. Universal service financing in competitive postal markets: one size does not fit all. Liège: CREPP - Centre de recherche en Economie Publique et de la Population; 2010 [cited 2014 Oct 18]. Available from:http://www2.ulg.ac.be/crepp/papers/ crepp-wp201004.pdf

[4] Oxera. Funding universal service obligations in the postal sector. Oxford: Oxera; 2007 [cited 2014 Nov 23]. Available from: http://www.oxera.com/Oxera/ media/Oxera/Funding-the-USO-in-the-postal-sector. pdf?ext=.pdf

[5] Ralević P, Dobrodolac M, Marković D. Using a nonparametric technique to measure the cost efficiency of postal delivery branches. Cent Europ J Oper Res. 2014. doi:10.1007/s10100-014-0369-0

[6] Ambrosini X, Boldron F, Roy B. Universal Service Obligations in the Postal Sector - Economic Learnings from Cross-Country Comparison. In: Crew MA, Kleindorfer PR, editors. Progress toward Liberalization of the Postal and Delivery Sector. New York: Springer Science + Business Media; 2006 [cited 2014 Sep 21]. Available from: http://www.springer.com/cda/content/document/cda_downloaddocument/9780387297439-c2. pdf?SGWID=0-0-45-418415-p88893028

[7] European Union. Directive 97/67/EC of the European Parliament and of the Council of 15 December 1997. Brussels: European Parliament and Council; 1997.

[8] European Union. Directive 2002/39/EC of the European Parliament and of the Council of 10 June 2002 Brussels: European Parliament and Council; 2002.
[9] European Union. Directive 2008/6/EC of the European Parliament and of the Council of 20 February 2008. Brussels: European Parliament and Council; 2008.

[10] Spajić D, Šapina K. AMQM system for measuring the quality of postal services. Promet. 2007;19(2): 129-137.

[11] Serbia. The Regulatory Agency for Electronic Communications and Postal Services - RAPUS. Ordinance on Quality Standards for the Provision of Universal Postal Service. Belgrade: RAPUS; 2010.

[12] Serbia. The Regulatory Agency for Electronic Communications and Postal Services - RAPUS. Rules on amendments to the Ordinance on Quality Standards for the Provision of Universal Postal Service. Belgrade: RAPUS; 2010.

[13] Bass FM. New Product growth model for consumer durables. Manage Sci. 1969;15(5):215-227. doi:10.1287/mnsc.15.5.215

[14] Lilien GL, Rangaswamy A, De Bruyn A. Principles of Marketing Engineering. 2nd ed. Pennsylvania: DecisionPro; 2013.

[15] Satoh D. A discrete Bass model and its parameter estimation. J Oper Res Soc Jpn. 2001;44(1):1-18.

[16] Mahajan V, Muller E, Bass FM. Diffusion of new products: Empirical generalizations and managerial uses. Market Sci. 1995;14(3):G79-G88. doi:10.1287/ mksc.14.3.G79

[17] Radojičić V, Bakmaz B. The application of quantitative methods of forecasting in telecommunications [in Serbian]. Belgrade: Faculty of Transport and Traffic Engineering; 2010.

[18] Universal Postal Union. UPU database. Bern: Universal Postal Union; [cited 2014 Sep 28]. Available from: http://pls.upu.int/pls/ap/ssp_report.main? p_language $=$ AN\&p_choice $=$ BROWSE 